\title{
PENERAPAN MODEL PEMBELAJARAN KNISLEY BERBASIS KONTEKSTUAL PADA MATERI LINGKARAN UNTUK SISWA KELAS VIII MTSN 7 KEDIRI TAHUN PELAJARAN 2019/2020
}

\author{
LULUK AZIZATUL MA'RIFAH \\ MTsN 7 Kediri \\ Email : lulukazizatu181@gmail.com
}

\begin{abstract}
ABSTRAK
Penelitian ini bertujuan menerapkan model pembelajaran knisley berbasis kontekstual pada materi lingkaran untuk siswa kelas VIII C MTsN 7 Kediri Tahun Pelajaran 2019/2020. Jenis penelitian ini adalah penelitian tindakan kelas dan subjek penelitian ini adalah siswa kelas VIII C MTsN 7 Kediri Tahun Pelajaran 2019/2020, dengan jumlah siswa sebanyak 32 siswa pada materi lingkaran. Objek penelitian ini adalah keseluruhan proses pembelajaran matematika dengan menggunakan model pembelajaran Knisley berbasis kontekstual. Instrumen penelitian ini yaitu lembar observasi, dan tes. Langkah penelitian dengan menggunakan model pembelajaran Knisley meliputi: 1) Konkret-Reflektif, guru menjelaskan konsep berdasarkan pengetahuan yang telah diketahui siswa; (2) Konkret-Aktif, guru memberikan tugas dan dorongan agar siswa melakukan percobaan, mengukur, atau membandingkan untuk menemukan konsep; (3) Abstrak-Reflektif, siswa membuat atau memilih pernyataan yang terkait dengan konsep baru, dan juga menyangkal pernyataan yang salah; (4) Abstrak-Aktif, siswa latihan memecahkan masalah menggunakan konsep baru. Hasil penelitian menunjukkan bahwa peneliti dapat menerapkan model pembelajaran Knisley berbasis kontekstual pada materi lingkaran dengan baik. Hal ini dapat dilihat dari hasil analisis penelitian yang diperoleh peneliti pada hasil lembar observasi dan tes akhir siklus. Hasil observasi menunjukkan bahwa prosentase aktivitas guru mencapai $92,26 \%$ dengan kategori sangat baik, dan hasil observasi aktivitas siswa prosentasenya $89,88 \%$ dengan kategori baik. Sedangkan secara klasikal ketuntasan yang dicapai siswa pada tes akhir siklus adalah $90.625 \%$ yakni dari 32 siswa kelas VIII C MTsN 7 Kediri, ada 29 siswa yang nilainya memenuhi Kriteria Ketuntasan Klasikal $(\mathrm{KKM}) \geq 76$. Sehingga penelitian dengan Penerapan Model Pembelajaran Knisley berbasis kontekstual pada materi lingkaran, pada siswa kelas VIII C MTsN 7 Kediri dikatakan berhasil.
\end{abstract} Kata Kunci: Model Pembelajaran Knisley Berbasis Kontekstual, Lingkaran.

\section{PENDAHULUAN}

Matematika merupakan ilmu dasar yang mempunyai peranan penting dalam perkembangan ilmu pengetahuan dan tehnologi. Banyak siswa memandang matematika sebagai bidang studi yang paling sulit. Padahal Dimyati dan Mujiono (2013: 238) mengemukakan bahwa dalam proses belajar siswalah yang menentukan terjadi atau tidaknya. Untuk bertindak belajar siswa menghadapi masalah-masalah secara intern. Jika siswa tidak dapat mengatasi masalahnya, maka ia tidak belajar dengan baik. Faktor intern yang dialami dan dihayati oleh siswa yang berpengaruh pada proses belajar yaitu sikap terhadap belajar, motivasi belajar, konsentrasi belajar, menggali hasil belajar yang tersimpan, kemampuan berprestasi atau unjuk hasil belajar, rasa percaya diri siswa, intelegensi dan keberhasilan siswa, kebiasaan belajar, serta cita-cita siswa. Dengan kata lain aktivitas belajar dapat meningkat bila program pembelajaran disusun dengan baik.

Permasalahan yang dihadapi di MTsN 7 Kediri diantaranya kurangnya minat dan antusias siswa dalam proses pembelajaran sehingga berimbas pada kurangnya keaktifan siswa saat KBM berlangsung, serta siswa kelas VIII masih kesulitan dalam memahami konsep matematika, yaitu pada materi lingkaran. Sebagai contoh saat siswa diberikan soal menentukan keliling lingkaran dari sebuah persegi yang terletak tepat di dalam sebuah lingkaran dengan diketahui panjang sisi persegi tersebut, masih banyak siswa yang langsung menggunakan ukuran panjang sisi persegi dalam mencari keliling lingkaran, padahal jawaban yang benar dari 
permasalahan itu adalah mencari diameter lingkaran dahulu dengan cara mencari diagonal dari bangun persegi. Dari contoh di atas, sangat jelas bahwa siswa masih kesulitan menentukan konsep dasar materi yang sedang mereka pelajari.

Seorang guru dituntut untuk mengembangkan pengetahuan siswa dan memilih metode pembelajaran yang efektif untuk membantu siswa memahami konsep matematika. Hal ini penting agar dapat memunculkan antusiasme siswa, menawarkan ide dan proses dalam bentuk yang mudah dipahami siswa, dan menghidupkan kelas dengan suasana yang menyenangkan. Salah satu model yang dapat digunakan yaitu model pembelajaran tipe Knisley berbasis kontekstual.

Pembelajaran kontekstual merupakan konsep belajar dan mengajar yang membantu guru mengaitkan antara materi yang diajarkannya dengan situasi dunia nyata siswa dan mendorong siswa membuat hubungan antara pengetahuan yang dimilikinya dengan penerapannya dalam kehidupan mereka sebagai anggota keluarga, warga negara, dan pekerja (Komalasari, 2010: 6). Sedangkan model pembelajaran Knisley sendiri merupakan model pembelajaran yang mengacu pada model pembelajaran Kolb yang berpendapat bahwa "... $a$ student's learning style is determined by two factors-whether the student prefers the concrete to the abstract, and whether the student prefers active experimentation to reflective observation"” (Knisley, 2003).

Berdasarkan permasalahan di atas, maka diterapkan model pembelajaran knisley berbasis kontekstual pada materi lingkaran untuk siswa kelas VIII MTsN 7 Kediri. Model pembelajaran Knisley dipilih dengan harapan membantu siswa yang mengalami kesulitan belajar, terutama konsep belajar serta memungkinkan siswa terlibat aktif dalam proses belajar mengajar, mengembangkan daya pikir untuk berfikir yang lebih kreatif sehingga termotivasi untuk mengikuti proses pembelajaran

\section{METODE PENELITIAN}

Subjek pada penelitian ini adalah siswa kelas VIII C MTsN 7 Kediri pada tahun pelajaran 2019/2020. Di kelas VIII C ini terdapat 32 siswa yang terdiri dari 10 siswa laki-laki dan 22 siswa perempuan. Sedangkan untuk materi yang digunakan oleh peneliti adalah salah satu materi pada mata pelajaran Matematika semester II yaitu keliling dan luas lingkaran. Peneliti memilih materi ini karena pada umumnya siswa masih mengalami kesulitan dalam memahami materi keliling dan luas daerah lingkaran meskipun telah dipelajari pada jenjang sebelumnya, dan materi ini juga sesuai untuk digunakan penerapan model pembelajaran Knisley berbasis kontekstual.

Penelitian ini menggunakan pendekatan penelitian kualitatif. Bogdan dan Taylor (dalam Moleong, 2008: 3) mendefinisikan Metodologi Kualitatif sebagai prosedur penelitian yang menghasilkan data deskriptif berupa kata-kata tertulis atau lisan dari orang-orang dan perilaku yang dapat diamati. Pada pendekatan kualitatif ini hal terpentingnya adalah hasil analisis datanya, sedangkan data-data kuantitatif, seperti nilai tes, hasil pengamatan, dan sebagainya hanya merupakan data pendukung.

Model penelitian tindakan kelas ini menggunakan guru sebagai peneliti dengan acuan model siklus Penelitian Tindakan Kelas (PTK) yang dikembangkan oleh Kemmis dan Taggart, dimana setiap siklus terdiri atas perencanaan (Planning), pelaksanaan tindakan (acting), pengamatan (observing), dan refleksi (reflecting). (Arikunto, 2006: 92)

Berdasarkan model Kemmis dan Taggart tersebut, maka peneliti membuat rancangan penelitian yang telah dimodifikasi. Adapun rancangan kegiatan tiap-tiap siklus dapat dilihat pada gambar berikut. 


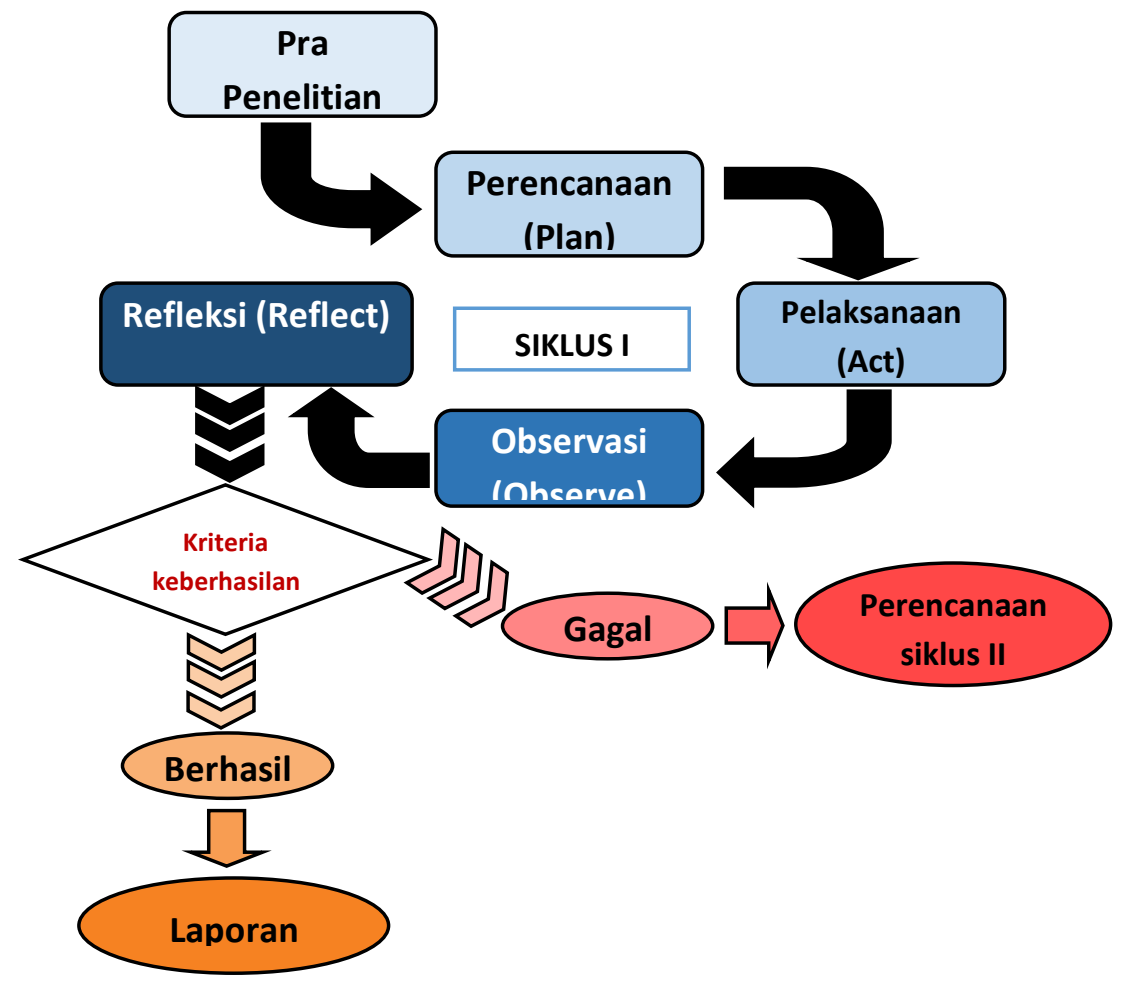

Gambar 1. Modifikasi Rancangan Penelitian Dari Model Kemmis dan Mc Taggart

Berdasarkan alur rancangan penelitian diatas, langkah penelitian dimulai dari pra penelitian, perencanaan (plan), pelaksanaan (act), observasi (observe), sampai refleksi, apabila gagal maka kembali ke perencanaan (plan), dan apabila berhasil maka dilanjutkan dengan membuat laporan.

Instrumen yang digunakan dalam penelitian ini dibagi menjadi dua, pertama instrumen pembelajaran berupa silabus, RPP, bahan ajar, Lembar Kerja Kelompok(LKK) dan pedoman penilaian LKK dan kedua instrumen penelitian berupa lembar observasi yang terdiri dari dua macam, yaitu lembar observasi guru dan lembar observasi siswa dan tes. Teknik pengambilan data dengan metode observasi dan metode tes.

Hasil dari observasi dianalisis dengan penskoran. Pensekoran ini dilakukan dengan memberi skor pada setiap pernyataan dari masing-masing aspek yang dinilai. Formulasi prosentase nilai rata-rata di peroleh dengan cara berikut:

$$
\text { Prosentase nilai rata-rata } \mathrm{NR}=\frac{\text { jumlah skor }}{\text { jumlah skor maksimal }} \times 100 \%
$$

Prosentase skor yang diperoleh dikualifikasi dengan menggunakan kriteria sebagai berikut:

Tabel 1. Kualifikasi Prosentase Skor Observasi

\begin{tabular}{|l|l|l|}
\hline No & Rentang Skor & Kualifikasi \\
\hline 1 & $\begin{array}{l}90 \% \quad \leq N R \leq \\
100 \%\end{array}$ & Sangat Baik \\
\hline 2 & $80 \% \leq N R \leq 90 \%$ & Baik \\
\hline 3 & $70 \% \leq N R \leq 80 \%$ & Cukup \\
\hline 4 & $60 \% \leq N R \leq 70 \%$ & Kurang \\
\hline 5 & $0 \% \leq N R<60 \%$ & $\begin{array}{l}\text { Sangat } \\
\text { Kurang }\end{array}$ \\
\hline
\end{tabular}

Dalam pengumpulan data yang berupa tes soal, peneliti menggunakannya untuk mengetahui ketuntasan belajar siswa secara individu dan secara klasikal. Pemberian skor berdasarkan kemampuan siswa pada saat menyelesaikan ulangan harian. Kemudian dari skor 
dapat ditafsirkan tentang ketuntasan siswa yang dibagi menjadi dua yaitu ketuntasan individu dan ketuntasan klasikal.

a. Ketuntasan Individu

Siswa dapat dikatakan berhasil dalam pembelajaran setelah mencapai ketuntasan minimal (KKM) pada pembelajaran yaitu dengan nilai ketuntasan individu $\geq 76$, sehingga dapat melanjutkan pada materi berikutnya. Sebaliknya siswa yang taraf penguasaannya kurang dari $76 \%$ atau dengan nilai di bawah 76 maka siswa tersebut dikatakan belum berhasil dalam mengikuti proses pembelajaran.

b. Ketuntasan Klasikal

Keberhasilan dalam kelas mencapai ketuntasan belajar jika paling sedikit $76 \%$ data dalam jumlah siswa dalam kelas tersebut mencapai ketuntasan perorangan dengan ketuntasan sebagai berikut: Jika jumlah siswa yang mencapai ketuntasan belajar $\geq 76 \%$ dari jumlah siswa keseluruhan dalam kelas maka kelas tersebut maka dapat melanjutkan ke materi berikutnya. Jika jumlah siswa yang mencapai ketuntasan belajar $<76 \%$ dari jumlah siswa keseluruhan dalam kelas belum tercapai ketuntasan dalam belajarnya, maka harus melakukan remidial.

\section{HASIL DAN PEMBAHASAN}

\section{Hasil}

\section{Hasil Observasi Aktifitas Guru dan Aktifitas Siswa}

Observasi dilaksanakan pada saat pembelajaran berlangsung pada pertemuan 1 pada materi menemukan pendekatan nilai phi dan menentukan rumus keliling dan luas lingkaran dan pertemuan 2 pada materi menentukan rumus luas lingkaran dan menghitung luas lingkaran. Observasi dilakukan oleh dua orang observer yaitu teman guru mata pelajaran matematika yang diberikan lembar observasi. Rekapitulasi hasil observasi aktivitas guru dan aktivitas siswa disajikan pada tabel 2.

Tabel 2. Rekapitulasi Hasil Observasi

\begin{tabular}{|c|c|c|c|c|}
\hline Keterangan & $\begin{array}{l}\text { Pertemuan } \\
1\end{array}$ & $\begin{array}{l}\text { Pertemuan } \\
2\end{array}$ & $\begin{array}{l}\text { Rata- } \\
\operatorname{rata}(\%)\end{array}$ & $\begin{array}{l}\text { Kriteria Taraf } \\
\text { Keberhasilan }\end{array}$ \\
\hline $\begin{array}{l}\text { Aktifitas } \\
\text { guru }\end{array}$ & $89,28 \%$ & $95,24 \%$ & $92,26 \%$ & Sangat Baik \\
\hline $\begin{array}{l}\text { Aktifitas } \\
\text { Siswa }\end{array}$ & $89,28 \%$ & $92,86 \%$ & $89,88 \%$ & Baik \\
\hline
\end{tabular}

2. Hasil Analisis Nilai Tes Akhir Siklus

Di pertemuan terakhir, yaitu pertemuan ketiga dilaksanakan evaluasi (Tes Akhir Siklus). Evaluasi yang dilaksanakan adalah dengan menggunakan tes Essay, yaitu soal yang masing-masing mengandung permasalahan dan menuntut penguraian sebagai jawabannya. Tujuan dari menguraikan jawaban yaitu untuk mengetahui sejauh mana siswa mendalami sesuatu masalah yang diteskan terutama materi keliling dan luas lingkaran. Selain itu, dengan tes Essay sedikit sekali memberi kesempatan kepada siswa untuk menerka jawaban ataupun menyontek teman. Hasil Analisis Nilai Tes Akhir Siklus disajikan pada tabel 3.

Tabel 3. Hasil Analisis Nilai Tes Akhir Siklus

\begin{tabular}{|ll|l|}
\hline \multicolumn{2}{|l|}{ Nilai Rata-Rata Kelas } & 86.093 \\
\hline $\begin{array}{l}\text { Jumlah Ketuntasan } \\
\text { Individu }\end{array}$ & 29 \\
\hline $\begin{array}{l}\text { Prosentase } \\
\text { Klasikal }\end{array}$ & Ketuntasan & $90.625 \%$ \\
\hline Kategori & Berhasil \\
\hline
\end{tabular}




\section{Pembahasan}

Secara umum keterlaksanaan penelitian mengenai pembelajaran matematika dengan model pembelajaran Knisley berbasis kontekstual pada siklus I sudah sesuai dengan tahapan pada pedoman observasi pembelajaran dan Rencana Pelaksanaan Pembelajaran (RPP) yang sudah disusun peneliti. Penelitian ini dilaksanakan dalam tiga kali pertemuan, Berdasarkan hasil penelitian yang dilaksanakan pada siklus I dapat dideskripsikan sebagai berikut:

1. Deskripsi penerapan model pembelajaran Knisley berbasis kontekstual pada materi keliling dan luas lingkaran.

Pada penelitian ini model yang digunakan ialah model pembelajaran Knisley berbasis kontekstual pada materi keliling dan luas. Kelebihan model pembelajaran matematika Knisley ini terlihat pada saat eksperimen/ percobaan menemukan nilai phi, rumus keliling, serta luas lingkaran dengan bantuan Lembar Kerja Kelompok (LKK), dimana untuk melakukannya siswa harus berdiskusi dengan kelompok masing-masing yaitu dengan saling bertukar informasi, pengetahuan, dan pendapat. Adapun 4 tahapan dalam strategi ini meliputi:

a. Konkret-Reflektif

Guru melakukan tahap ini bertujuan untuk menggali pengetahuan awal sebagai materi prasyarat dan modal siswa untuk mengerjakan LKK. Dengan mengaitkan pengetahuan yang telah dimiliki siswa dengan pengetahuan baru yang disampaikan dengan berbasis kontekstual, siswa akan lebih mudah memahami dan menerapkannya dalam penyelesaian soal - soal yang berkaitan denga keliling dan luas lingkaran.

b. Konkret-Aktif

Model Knisley ini mengajak siswa untuk menggali semua potensi yang dimiliki dan memahami konsep dari proses terbentuknya hingga proses penerapannya dalam latihan soal. Siswa juga bisa menilai sebuah rumus/konsep itu benar atau keliru dari sudut pandang proses menemukannya. Dengan model pembelajaran Knisley siswa diajak untuk menemukan rumus melalui sebuah eksperimen/ percobaan dengan menggunakan benda yang dia jumpai seharihari. Hal ini mengajak kita betapa pentingnya proses penemuan sebuah rumus dan mengajarkan siswa agar tidak terlalu percaya terhadap rumus jadi. Hal ini sesuai dengan Kinach (dalam Dedy, Mulyana, dan Sudihartinih, 2012: 105) yang menyatakan Pemahaman pada tingkat epistemik ini menguatkan cara berpikir yang digunakan pada tingkat pemahaman konsep dan pemecahan masalah.

c. Abstrak-Reflektif

Guru mengajak siswa untuk berani berpendapat dan menuliskan hasil temuannya di depan kelas untuk kemudian dipersentasikan. Setelah persentasi konsep yang mereka temukan di gunakan untuk mengerjakan latihan soal. Hal ini sejalan dengan Smith (dalam Mulyana, 2009 : 8) yang menyatakan setiap gaya belajar Knisley berarti mengaktifkan semua bagian otak sehingga pembelajaran menjadi lebih efektif.

d. Abstrak-Aktif

Pada tahap ini, Guru memberikan latihan soal secara individu serta siswa di ajak untuk membuat rancangan penyelesaian soal dengan penemuan konsep baru yang sudah di temukan. Siswa memberikan beberapa gagasan mengenai soal latihan tersebut dan guru menampungnya nanti pada saatnya guru dan siswa bersama-sama membuat gagasan penyelesaian soal latihan yang masih di tampung. Hal ini juga sejalan dengan penelitian Asih (dalam Nurhidayah, 2019) yang menyatakan bahwa dengan cara memberikan serangkaian pertanyaan-pertanyaan kepada peserta didik akan membantu guru dalam mengarahkan dan membimbing peserta didik untuk menemukan sebuah konsep.

Dilihat deskripsi pelaksanaan tindakan pada pertemuan pertama menunjukkan bahwa terlihat banyak siswa masih bingung dalam mengerjakan LKK ini. Hal ini disebabkan karena siswa belum paham apa yang di minta dalam LKK tersebut. Penyebab lainnya yang diduga menjadikan siswa masih bingung dalam mengerjakan LKK adalah kurang terbiasanya siswa menggunakan model pembelajaran matematika Knisley. Akibatnya ada salah satu tahapan yang tidak dilaksanakan kartena siswa asyik pada tahapan sebelumnya. 


\section{EDUCATIONAL : Jurnal Inovasi Pendidikan dan Pengajaran Vol. 1 No. 3 Agustus 2021 e-ISSN : 2775-2593 | p-ISSN : 2775-2585}

Pada pertemuan pertama terlihat masih kurang diskusi kelompok sehingga kemampuan dalam mengerjakan LKK tersebut cenderung kurang. Selain itu banyak siswa yang bertanya kepada guru. Hal ini menunjukkan bahwa tahapan pembelajaran Knisley pada pertemuan pertama belum berjalan secara efektif.

Dilihat dari deskripsi pelaksanaan tindakan pada pertemuan kedua, siswa sudah bisa memahami apa maksud dari LKK tersebut dan dapat mengerjakan dengan baik. Pada pertemuan kedua tahap yang pada pertemuan pertama tidak terlaksana, pada pertemuan kedua bisa terlaksana dengan baik dan sesuai jadwal. Pada tahap berikutnya, siswa terlihat berdiskusi dengan teman kelompoknya untuk menyelesaikan permasalahan yang ada di LKK. Siswa pun terlihat sangat antusias dalam mengerjakan tahap ini. Hal ini kemungkinan besar siswa sudah mengerti dengan maksud dari LKK tersebut dengan baik.

Berdasarkan data siklus I, hasil observasi kegiatan guru yang dilakukan oleh pengamat berdasarkan tabel 2 dapat dilihat bahwa prosentase nilai rata-rata aktivitas guru pada pertemuan ke-1 adalah 89,28\% dengan kriteria baik, pada pertemuan ke-2 adalah 92,26\% dengan kriteria sangat baik. Dan pada tabel 2 menunjukkan aktivitas guru dengan prosentase 92,26\% dengan kriteria sangat baik.

Berdasarkan data hasil observasi kegiatan siswa yang dilakukan oleh pengamat berdasarkan tabel 2 dapat dilihat bahwa prosentase nilai rata-rata aktivitas siswa pada pertemuan ke-1 adalah 89,28\% dengan kriteria baik, sedangkan pada pertemuan ke-2 adalah $92,86 \%$ dengan kriteria sangat baik. Prosentase rata-rata aktivitas siswa yang ditunjukkan pada tabel 4.8 yaitu sebesar $89,88 \%$ dengan kriteria baik.

Dan pada akhir pelaksanaan tindakan kegiataan pembelajaran diadakan evaluasi tes akhir siklus. Hasil evaluasi yang dilakukan oleh peneliti pada kegiatan pembelajaran siklus I menunjukkan bahwa siswa sudah mampu merespon soal-soal tes akhir siklus sesuai dengan yang diharapan peneliti. Skor rata-rata hasil tes kegiatan pembelajaran siklus I adalah 86,86 dengan masih ada siswa dari keseluruhan jumlah siswa yang memperoleh skor $\leq 76 \%$ sebanyak 3 siswa dari 32 siswa. Sebagian besar siswa sudah bisa memahami materi dengan baik. Hanya sebagian kecil siswa saja yang belum paham. Kriteria keberhasilan yang telah ditetapkan pada kegiatan pembelajaran sudah tercapai. Maka pembelajaran berakhir dan tidak perlu dilanjutkan pada siklus berikutnya.

Penelitian sebelumnya yang dilakukan oleh Sigit Adi Wibowo pada tahun 2014 dengan judul "Penerapan Model Pembelajaran Knisley dengan Metode Brainstorming untuk meningkatkan Kemampuan Komunikasi Matematik" dapat meningkatkan komunikasi matematik pada siswa. Hal ini dapat dilihat dari 1) kemampuan siswa menjelaskan ide/ gagasan secara lisan/ tulisan dari kondisi awal (20\%) meningkat menjadi $(77,14 \%)$, 2) kemampuan siswa menyatakan suatu situasi, gambar, diagram, atau benda nyata ke dalam bahasa, simbol, ide, atau model matematika dari kondisi awal (20\%) meningkat menjadi $(68,57 \%)$, 3) kemampuan siswa mendengarkan dan berdiskusi tentang matematika dari kondisi awal $(22,86 \%)$ menjadi (71,43\%). Sehingga, dengan meningkatnya kemampuan komunikasi matematik siswa, akan berdampak pula pada hasil belajar siswa yang juga meningkat.(Wibowo, 2014)

Berdasarkan hasil evaluasi hasil tes dan hasil observasi, maka dapat disimpulkan bahwa proses pembelajaran yang dilaksanakan sudah sesuai dengan yang direncanakan atau dapat dikatakan berhasil.

\section{KESIMPULAN}

1. Pemahaman materi tentang lingkaran dengan model Knisley dapat meningkatkan ketercapaian hasil ketuntasan belajar siswa pada pengamatan di kelas VIII C MTsN 7 Kediri

2. Model pembelajaran Knisley dapat menjadi salah satu alternative dalam meningkatkan rasa ingin tahu siswa serta meningkatkan keaktifan siswa 


\section{DAFTAR PUSTAKA}

Arikunto, Suharsimi. (2006). Prosedur Penelitian. Jakarta: PT Rineka Cipta.

Dedy, Endang., Mulyana, Endang., Sudihartinih, Eyus. (2015). Pengembangan Bahan Ajar Kalkulus Vektorberdasarkan Model Pembelajaran Matematikaknisley Sebagai Upaya Meningkatkan Kompetensi Matematika Mahasiswa. Pythagoras: Jurnal Pendidikan Matematika, Vol. 7, No. 1

Dimyati dan Mujiono. (2013). Belajar dan Pembelajaran. Jakarta : PT Rineka Cipta

Knisley, Jeff. (2002). A Four-Stage Model of Mathematical Learning. The Mathematics Educator, Vol. 12, No. 1

Komalasari, K.(2010). Pembelajaran Kontekstual: Konsep dan Aplikasi.Bandung : Refika Aditama

Moleong, Lexy .J. (2008). Metodologi Pendidikan Kualitatif Edisi Revisi. Bandung: Remaja Rosdakarya.

Mulyana, Endang. (2009). Pengaruh Model Pembelajaran Knisley terhadap Peningkatan Pemahaman Matematika Siswa SMA IPA (online), (http: //journal.fpmipa.upi.edu). Diakses tanggal: 20 Desember 2019.

Nurhidayah, \& Ade Susanti. (2019). Pengaruh Model Pembelajaran Knisley Terhadap Kemampuan Koneksi Matematis Siswa Kelas VIII SMP Negeri 7 Merangin. MatEdukasia, 4(2), 36-44. https://doi.org/10.3020/mat-edukasia.v4i2.236

Wibowo, Sigit Adi. (2014). Penerapan Model Pembelajaran Knisley dengan Metode Brainstorming untuk meningkatkan Kemampuan Komunikasi Matematik (online). (http://eprints.ums.ac.id/30529/13/NASKAH_PUBLIKASI.pdf). Diakses tanggal: 20 Desember 2019. 